\title{
A COMPARATIVE VIEW ON SECURITY CULTURE AS REFLECTED IN ROMANIA'S NATIONAL DEFENSE STRATEGIES
}

\author{
Ruxandra Buluc ${ }^{1}$ \\ "Carol I" National Defence University
}

\begin{abstract}
The present paper aims at analyzing the concept of security culture by, firstly, pinpointing its theoretical underpinnings and, secondly, by undertaking a qualitative thematic analysis of the concept as it is presented in Romania's National Defense Strategies from the last decade. The objective is to examine to what extent the evolutions in the security environment are mirrored in the understanding of the concept at strategic level and in the objectives and actions proposed for the implementation of security culture at societal level.
\end{abstract}

Keywords: strategic culture; security culture; security environment; threats; risks; vulnerabilities.

\section{INTRODUCTION}

Security culture is a concept of increasing importance in contemporary society because there are several transformations that have occurred in recent decades that have led to a change in the paradigm of security itself. These changes pertain to international relations e.g. the end of the Cold War; to a more intense scrutiny on the role that culture plays in the field of security; and to the transformations of the informational and communicational media. The present article is aimed at analyzing the themes that have been considered relevant as pertaining to security culture in the Romanian National Defence Strategies. The reason for choosing to analyze these themes is that they determine the public sphere discussions on the issues of security culture, as well as on the measures needed to build a resilient security culture, as these themes become the narratives that will then be the basis for communication strategies meant to build and strengthen security culture. These themes are the building blocks of security culture.

\section{THE EVOLUTION OF SECURITY CULTURE IN LIGHT OF THE TRANSFORMATIONS IN THE SECURITY ENVIRONMENT}

In order to fully grasp what security culture is and how it can be achieved, one needs to first examine the terms that make it up. Culture can have many definitions and interpretations which could be summarized under four main categories: (1) to the products that it is manifest in; (2) the mechanisms, patterns and behaviors that lead to its formation, transmission and that are engrained in it; (3) the attitudes, values, knowledge and beliefs it encapsulates; (4) the process of fostering growth and development. As A. L. Kroeber and Clyde Kluckholn explain in their extensive study of culture: "Culture consists of patterns, explicit and implicit, of and for behavior acquired and transmitted by symbols, constituting the distinctive achievement of human groups, including their embodiments in artifacts; the essential core of culture consists of traditional (i.e., historically derived and selected) ideas and especially their attached values; culture systems may, on the one hand, be considered as products of action, on the other hand as conditioning elements of further action" (Kroeber \& Kluckholn $1952,357)$ As it can be seen, culture is a shared schema of interpretation for a certain group; however, this does not mean that culture implies homogeneity or lack of debates or differentiations within a certain group. Members of the group could be experts or novices, they might have differences or variations in knowledge or values or beliefs, communities that develop cultures and function in a cultured environment might have factions, but they share overall values and interests that are meant

\footnotetext{
${ }^{1}$ Corresponding author: buluc.ruxandra@myunap.net
} 
to protect and ensure the wellbeing and survival of their communities. This utilitarian and pluralistic view of culture is the background for the development of contemporary security culture.

The term security culture has evolved from the Cold War term strategic culture, first introduced by J. Snyder and defined as "the sum total of ideas, conditioned emotional responses, and patterns of habitual behavior that members of a national strategic community have acquired with regard to [nuclear strategy]" (Snyder 1977, 8). It evolved from a culture of isolation, fear and distrust that the two geostrategic blocks, NATO countries and Warsaw Treaty countries separated by the Iron Curtain, had with respect to one another. It provided doctrines and mechanisms meant to manage and control the conflictual situation that simmered between the two blocks for over 50 years. As such it was focused mainly outward, towards enemies but also towards allies, and it was based on clear delimitations and roles that were assigned to all those targeted. Strategic culture as such did not focus on the situation within the borders of the countries, or on the domestic public's attitudes towards security. Strategic culture is a matter of the image a state or organization promotes towards those that are not part of their respective communities. As such, it was more homogeneous in the time of the Cold War when dissention on the part of the Warsaw Treaty countries was extremely difficult, and the NATO countries maintained their image of morally superior, progressive, free and developed societies.

The concept of strategic culture continued to evolve in international relations studies. Lucian Pye (1985) viewed strategic culture as a generator of preferences and as a vehicle for the transmission of values and for the renewal of these values. Rosen further refined the term by explaining that strategic culture includes "the beliefs and assumptions that frame (...) choices about international military behavior, particularly those concerning decisions to go to war, preferences for offensive, expansionist or defensive modes of warfare, and levels of wartime casualties that would be acceptable" (Rosen 1996, 12). In these definitions, the focus remains of the external, international, conflictual nature of strategic culture as it is still influenced by traditional views of warfare as a clearly temporally, spatially and auctorially delimitated engagement. A.I. Johnston takes the definition of strategic culture one step further by analyzing more closely the traits of culture with a focus on the relation between cultural patterns and behaviors. He explains that the former affects the latter in the sense that patterns limit behavioral options and affect how members of a particular culture learn from the interaction with their environment (Johnston 1995, 45). In terms of strategic culture, this means that leaders can choose from a set of strategic choices which can allow for predictions with respect to targeted behavior and which can be enacted in a certain context.

The concept was further enhanced by C.S. Gray who defined it as: "the master narrative, is the disarmingly elementary, even commonsensical, idea, that a security community is likely to think and behave in ways that are influenced by what it has taught itself about itself and its relevant contexts. And that education, to repeat, rests primarily upon the interpretation of history and history's geography (or should it be geography's history?)" (Gray 2006, 7). He extended the meaning to include the image that a society has of itself, the image that it promotes and teaches about itself, as influenced by the historical and geographical context in which it finds itself. Thus, strategic culture in Gray's understanding is more encompassing and it signals the shift to what security culture is today. This shift has been caused by the increasingly complex and complicated geopolitical contexts, determined by sometimes conflicting geostrategic interests, by the unpredictable and hybrid security challenges and demographic changes. The more complex contemporary warfare has become and the more the classical delimitations between actors and types of actions that belligerent parties can engage in during war have been blurred, the more the need for a more nuanced, extensive and inclusive view of strategic culture has become. This trend has led to the adoption of the concept security culture, whose focus, as we shall further analyze, is placed more on domestic audiences than on international relations.

Moreover, the adoption of the concept of security culture has also been warranted by the societal transformations that have also occurred. Once the Cold War ended and communication among all countries, regardless of their past political regimes, became more widespread, the populations could make comparisons with other societies and examine their own societies and cultures in light of an extended array of values, attitudes, behaviors, which means, in light of other cultural lenses. Information exchange and sharing means that cultures become more comparable, 
more diverse approaches are encouraged, attitudes are being refined, values are being contested, supported, extended, modified, leading to development, but possibly also to deterioration or corruption. In other words, cultural interaction is an opportunity, however, it can also give rise to vulnerabilities and risks, when the values it is founded on are challenged and attacked, either from within or from without. In this new context, security culture becomes much needed in order to preserve the wellbeing of societies.

Security has an equally multifaceted definition with different interpretations depending on the theoretical framework that studied it. The understanding of the concept has also evolved from what it meant in traditional international relations when the focus was on the security of the state against outside aggressions more precisely military security, to what it means today, when the concept is widened both in scope as well as in audiences. This widening of the scope of security has been debated by Barry Buzan who explains that the concept of security is related to survival, and in order to be considered a security issue, a threat, be it military or non-military, has to be "an existential threat to a referent object by a securitizing actor who thereby generates endorsement for emergency measures beyond rules that would otherwise bind" (Buzan 1997, 13). These threats can be found in any of the sectors which are placed under the umbrella term of security (Buzan et al 1998, 21-23). For example, in the military the referent object is the state or another political entity and the existential treats usually pertain to the military, i.e. survival of the armed forces. In the political sector the existential threat is to the state, its sovereignty or ideology. In the economic sector, existential threats are more difficult to determine as the economic system, especially in a globalized world, can fluctuate but eventually balance itself. In the societal sector the referent object can refer to "collective identities that can function independent of the state, such as nations and religions" (Buzan et al 1998, 22-23). In the environmental sector, existential threat could range from particular ones, such as endangered species, to more general one, such as global warming. Buzan explains his approach to security and this explanation foretells the development of security culture which has to mitigate for the effects of various actors, on different security sectors. "The future management of security will have to include a handling of these actors, as for instance in strategies aimed at mitigating security dilemmas and fostering mutual awareness in security complexes" (Buzan 1997, 20). The strategic approach to existential security threats has become increasingly engrained in Romania's National Defence Strategies as our analysis in the second section will prove.

Bjørn Møller (2000) explains that there has been a refinement in the analysis of the addressee of security as well. Møller suggests three such levels: the state in which case security refers to sovereignty and power; collectivities, in which case it refers to identity; and individuals, in which case it refers to survival and well-being. As he explains, the levels are interconnected "State security may be worth striving for, but only to the extent that it contributes to the security, i.e. survival and well-being, of people." Thus individual and global security are, in fact, "two sides of the same coin".

This connection between all levels of security is becoming increasingly visible in the context of the transformations in the informational environment which are caused mainly by the increased use of social media and online information sources in order to form, inform and distort public opinion on issues varying from political, medical, cultural, economic, military etc. domains. Kavanagh and Rich (2018) analyze the current informational systems and conclude that we are witnessing what they call truth decay in contemporary society. They define this concept as the culmination of four trends:

1. "increasing disagreement about facts and analytical interpretations of facts and data;

2. a blurring of the line between opinion and fact;

3. the increasing relative volume, and resulting influence, of opinion and personal experience over fact;

4. declining trust in formerly respected sources of factual information" (Kavanagh \& Rich 2018, x-xi)

Given the fact that opinions are transmitted freely in the online environment and that one post could reach millions of people irrespective of its informational rigor or truth content, societies in their entireties could be affected, results of democratic processes could be tainted or reversed, the very fiber that holds societies, states, organizations, communities together could be frayed. This surge in disinformation and the decay of reliable sources of information have also led to a transformation of the 
understanding of security culture. Disinformation has become a major threat for all domains of security and for liberal democratic systems as such. P.W. Singer and Emerson T. Brooking (2018) analyze the ways in which social media turn from community building tools which foster constructive dialogue, into destructive instruments, whose effects can be comparable to those of wars because they are the perfect battleground for fake news dissemination. The authors notice that this duality is inherent to social media and it is based on the one hand on the evolutionary advantages of human beings: dynamism, adaptability, need to belong, but on the other hand, uses these advantages to the detriment of people, exposing them to disinformation campaigns, as people are badly equipped to handle the immense flux of information that they are exposed to almost instantaneously. However, "humans are unique in their ability to learn and evolve, to change the fabric of their surroundings" (Singer \& Brooking 2018, 285). The authors have uncovered five constant rules of online warfare, aka LikeWar (Singer \& Brooking 2018, 285-287).

First of all, "First, for all the sense of flux, the modern information environment is becoming stable", meaning that the internet has become the prevalent communicational medium and it will remain so for the foreseeable future. Second of all, the internet is a battlefield, not a promoter of peace and understanding. In fact, it is a platform on which actors, regardless of their nature and allegiances, compete in order to reach their goals and which they manipulate to serve their interests. The best and worst aspects of human nature compete on the internet to draw attention and engagement from the public. Thirdly, this battlefield changes how people think of information itself. If something happens, in this digital era, people automatically assume there is a digital trace of the event, a video, an online message, an image, and if the trace cannot be found, they are less likely or willing to believe the event happened; and no event has any power unless people believe it occurred. "The nature of this process means that a manufactured event can have real power, while a demonstrably true event can be rendered irrelevant. What determines the outcome isn't mastery of the "facts," but rather a back-and-forth battle of psychological, political, and (increasingly) algorithmic manipulation. Everything is now transparent, yet the truth can be easily obscured. "Fourthly, "war and politics have never been so intertwined" because the online environment and the means by which military or political competitions are won are practically identical, and the programmers in Silicon Valley have become global power vectors, whose decisions change battlefields and conflict outcomes. Last, all people are part of the warfare, surrounded by countless information battles and struggles, more or less visible, but whose common goal is to alter people's perceptions about the world they live in. Anything that people notice, like, distribute becomes a new attack. I would add here that in this ongoing influence war, people are both actors as well as targets or victims, are alternatively in positions of power or of subordination, and, for the most part, they are unaware of the effort made to change their perceptions, or, on the contrary, to reinforce their beliefs and to maintain them in the echo chambers they have been isolated in. Although the internet is the great social unifier and equalizer, it can in fact become, via fake news and disinformation, the greatest agent of separation, division, dissension builder, common denominator suppressor and polarization and radicalization agent.

From the point of view of security culture development, all these consequences and mechanisms of disinformation and truth decay affect the very perception of what security is, what individuals should expect security to represent for them. A mature security culture requires dialogue and agreement on its defining characteristics in order to be able to ensure and promote individual and societal security. The development of security culture is based on an extremely important process: an awareness of security which Roer defines as "knowing and perceiving a situation or a fact" (Roer 2015, 43), more precisely, an understanding of the situations that may represent risks and threats to individual security, of the vulnerabilities that some actors interested in attacking and destabilizing societies might take advantage of, as well as the identification of the opportunities by which the threats, risks and vulnerabilities could be turned into factors to increase social security. This understanding brings to the foreground the need to identify the necessary competences to efficiently respond to security threats, vulnerabilities and risks. In this security awareness-building process certain cultural values that are already fixed might be called into question and the cognitive dissonance that ensues might be hard to manage, especially if those aspects called into question are values or beliefs deeply ingrained in the respective groups' identities. 
In light of these developments, it is becoming increasingly important that states take an active role in implementing security culture at the level of their societies in order to promote the values that their societies are based on, to safeguard national interests from ill-intended intrusions, to enhance the resilience of the citizens in face of aggressive and ever more pervasive disinformation campaigns. In this respect, security culture operates at all three levels mentioned by Johnston (1995) individual, community and state as it is meant to strengthen the bonds that hold these societal structures together as well as to ensure that citizens are aware of the security issues that may affect them and have the necessary coping mechanisms to face them.

\section{QUALITATIVE THEMATIC ANALYSIS OF THE CONCEPT OF SECURITY CULTURE AS REFLECTED IN ROMANIA'S NATIONAL DEFENCE STRATEGIES}

In this section we provide a thematic analysis of the ways in which the concept of security culture has been approached in Romania's National Defence Strategies starting from 2010, the first time it was mentioned, until the latest Defence Strategy adopted in 2020. Our goal is to analyze how the concept has evolved both in understanding as well as in application by drawing a parallel to the evolution of the theories on security culture as well as of security environment itself as presented in the preceding section.

To meet this objective, we have firstly identified all references to security culture in the three National Defence Strategies analyzed, and we have coded those reference with respect to the following criteria: number of occurrences of the term, the audiences that it targets, the definition that is provided for security culture, the objectives it is supposed to meet and the actions that it entails.

It is important to note from the very beginning that National Defence Strategies employ a constructivist approach to security building in that they embody the idea that it is in the power of state and civil actors to collaborate in order to construct a secure society, resilient in the face of threats and risks and less exposed to vulnerabilities. This constructivist approach to security is based on a common discourse which fosters a common understanding of what a state on security is and what measures are needed in order for it to be achieved. To this end, it is of great importance to identify the themes that underlie the National Defence Strategies approach to security culture in order to ascertain how it could be proliferated to the societal level and which actors could play a role in materializing these themes into adequate narratives and discourse that could foster a common societal understanding and adherence to security culture.

\begin{tabular}{|c|c|c|c|c|c|c|}
\hline Strategy & $\begin{array}{c}\text { No of } \\
\text { occurrences }\end{array}$ & Chapters & Audiences & Definition & Objectives & Actions \\
\hline $\begin{array}{l}\text { NDS } \\
2010\end{array}$ & - & $\begin{array}{l}\text { The } \\
\text { intellectual, } \\
\text { educational } \\
\text { and cultural } \\
\text { dimension of } \\
\text { national } \\
\text { security }\end{array}$ & $\begin{array}{l}\text { a) The } \\
\text { state and } \\
\text { the civil } \\
\text { society } \\
\text { b) The } \\
\text { educational } \\
\text { system }\end{array}$ & $\begin{array}{l}\text { Values, norms, } \\
\text { attitudes or } \\
\text { actions that } \\
\text { determine the } \\
\text { understanding } \\
\text { and } \\
\text { assimilation of } \\
\text { the concept of } \\
\text { security and } \\
\text { other derived } \\
\text { concepts. }\end{array}$ & $\begin{array}{l}\text { a) Defence and the } \\
\text { accomplishment of } \\
\text { the state of } \\
\text { national security; } \\
\text { b) The } \\
\text { democratization of } \\
\text { the national } \\
\text { security and } \\
\text { defence field; } \\
\text { c) Expertise held } \\
\text { not only by the } \\
\text { state; } \\
\text { d) Dialogue } \\
\text { between the state } \\
\text { and civil society; } \\
\text { contributing to the } \\
\text { improvement of } \\
\text { governance in the } \\
\text { field of national } \\
\text { security and } \\
\text { defence. }\end{array}$ & \\
\hline $\begin{array}{l}\text { NDS } \\
2015\end{array}$ & 2 & $\begin{array}{l}\text { The } \\
\text { educational, } \\
\text { healthcare, } \\
\text { social and } \\
\text { demographic } \\
\text { dimension }\end{array}$ & $\begin{array}{l}\text { political } \\
\text { class and } \\
\text { the civil } \\
\text { society }\end{array}$ & $\begin{array}{l}\text { No definition } \\
\text { provided }\end{array}$ & $\begin{array}{l}\text { a) to promote } \\
\text { values, norms, } \\
\text { attitudes or actions } \\
\text { allowing for the } \\
\text { assimilation of the } \\
\text { national security } \\
\text { concept; }\end{array}$ & \\
\hline
\end{tabular}




\begin{tabular}{|c|c|c|c|c|c|c|}
\hline Strategy & $\begin{array}{c}\text { No of } \\
\text { occurrences }\end{array}$ & Chapters & Audiences & Definition & Objectives & Actions \\
\hline & & $\begin{array}{l}\text { Final } \\
\text { considerations }\end{array}$ & & & $\begin{array}{l}\text { b) the civil society } \\
\text { becomes involved } \\
\text { in the development } \\
\text { of the security } \\
\text { culture and in the } \\
\text { open debate of } \\
\text { security issues. }\end{array}$ & \\
\hline $\begin{array}{l}\text { NDS } \\
2020\end{array}$ & 11 & $\begin{array}{l}\text { Introduction } \\
1.1 \text { Romania - } \\
\text { promoter and } \\
\text { actor involved } \\
\text { in sustainable } \\
\text { international } \\
\text { partnerships, } \\
\text { regional pillar } \\
\text { of stability } \\
1.2 \text { Romania - } \\
\text { a state resilient } \\
\text { to threats, } \\
\text { security and } \\
\text { prosperity } \\
\text { provider for its } \\
\text { citizens } \\
2.3 . \text { National } \\
\text { security } \\
\text { objectives } \\
4.2 \text {. Risks } \\
4.3 \text {. Vulne- } \\
\text { rabilities } \\
5.1 .4 . \\
\text { Intelligence, } \\
\text { counter } \\
\text { intelligence } \\
\text { and security } \\
5.1 .8 . \\
\text { Education, } \\
\text { Health, Society } \\
\text { and } \\
\text { Demographics } \\
\text { (Societal } \\
\text { Dimension) } \\
5.3 \text {. Correlating } \\
\text { the lines of } \\
\text { action with } \\
\text { national } \\
\text { security } \\
\text { objectives in } \\
\text { terms of } \\
\text { threats, risks } \\
\text { and } \\
\text { vulnerabilities } \\
\text { Final } \\
\text { considerations }\end{array}$ & $\begin{array}{l}\text { a) all } \\
\text { Romanian } \\
\text { citizens } \\
\text { b) as many } \\
\text { society and } \\
\text { generation } \\
\text { segments } \\
\text { as possible }\end{array}$ & $\begin{array}{l}\text { No definition } \\
\text { provided }\end{array}$ & $\begin{array}{l}\text { a) to ensure } \\
\text { resilience and } \\
\text { good governance } \\
\text { for the benefit of all } \\
\text { Romanian citizens } \\
\text { b) to develop its } \\
\text { own rapid and } \\
\text { efficient response } \\
\text { mechanisms } \\
\text { c) to develop } \\
\text { mechanisms for } \\
\text { citizens' } \\
\text { understanding, } \\
\text { prevention and } \\
\text { response when } \\
\text { faced with threats, } \\
\text { risks or } \\
\text { vulnerabilities } \\
\text { impacting national } \\
\text { security } \\
\text { d) to create a } \\
\text { strong and resilient } \\
\text { state is } \\
\text { interdependent } \\
\text { with its citizens' } \\
\text { level of security } \\
\text { culture } \\
\text { e) to contribute to } \\
\text { understanding the } \\
\text { role that every } \\
\text { societal actor - } \\
\text { state, public } \\
\text { institutions, but } \\
\text { also private entities } \\
\text { (corporations and } \\
\text { individuals) - has } \\
\text { in the process of } \\
\text { ensuring national } \\
\text { security } \\
\text { f) to correlate the } \\
\text { lines of action with } \\
\text { the national } \\
\text { security objectives } \\
\text { will remain a } \\
\text { permanent, inter- } \\
\text { institutional effort, } \\
\text { supported by a } \\
\text { deeper dialogue } \\
\text { between the } \\
\text { institutions and the } \\
\text { citizens, with the } \\
\text { aim of } \\
\text { strengthening } \\
\text { security culture } \\
\text { and resilience. }\end{array}$ & $\begin{array}{l}\text { a) Strengthening the } \\
\text { security culture among } \\
\text { the decision-making } \\
\text { apparatus, considering } \\
\text { their status as } \\
\text { managers of classified } \\
\text { information, by raising } \\
\text { awareness of the main } \\
\text { counterintelligence } \\
\text { risks and vulnerabilities } \\
\text { that can facilitate the } \\
\text { manifestation of threats } \\
\text { to national security with } \\
\text { a major impact in terms } \\
\text { of national interests, as } \\
\text { well as from the } \\
\text { perspective of the } \\
\text { interests entailed by } \\
\text { partnerships; } \\
\text { b) Strengthening the } \\
\text { security culture among } \\
\text { the decision-making } \\
\text { apparatus, considering } \\
\text { their status as } \\
\text { managers of classified } \\
\text { information, by raising } \\
\text { awareness of the main } \\
\text { counterintelligence } \\
\text { risks and vulnerabilities } \\
\text { that can facilitate the } \\
\text { manifestation of threats } \\
\text { to national security with } \\
\text { a major impact in terms } \\
\text { of national interests. }\end{array}$ \\
\hline
\end{tabular}

The concept of security culture is first mentioned in the 2010 National Defense Strategy (NDS 2010). It only appears once but a definition of the term is given. As such, it refers to values, norms and actions meant to ensure an understanding and acceptance at a societal level of what security is. This signals that fact that security is viewed not solely at state level, but also at the level of the individuals that make up that society, and that education is responsible for disseminating security culture. To the extent that security culture presupposes a delimitation among values, an indication of what norms and actions are recommended in a particular society, it is important to notice that the definition does not provide any insight. The objectives it sets forth are also ambiguous, but it is clear 
that it encourages democratic collaboration between state and civil actors, with a focus on educating the latter in order to become actively involved in creating the state of security.

In the National Defense Strategy 2015-2019. A Strong Romania within Europe and the World, the concept of security culture appears in the chapter entitled "The educational, healthcare, social and demographic dimension", where one of the lines of action is "fostering the security culture, including through continuous education, aimed at promoting values, norms, attitudes or actions allowing for the assimilation of the national security concept" (NDS 2015, 14). More details about the concept are provided in the Guide to the National Defense Strategy, drafted by the presidency, in which security culture is defined as "the sum total of values, norms, attitudes or actions that determine the comprehension and assimilation at a societal level of the concept of security culture and those derived from it (national security, international security, collective security, insecurity, security policy etc.)" (Guide to NDS 2015, 7). As it can be noticed, the definition is taken over from NDS 2010. However, one important aspect that is mentioned in the Guide to the National Defense Strategy is that in a world in which security has become a main concern, each person needs to play a role in providing security. "This perspective places the citizen in a double position: of beneficiary as well as generator of security." (Guide to NDS 2015,14 ) This basically means that security becomes stronger at the societal level if it is clearly understood and assimilated at the individual level, and that it presupposes the cooperation among governmental and nongovernmental organizations, public and private entities meant "to promote knowledge, respect and mutual trust among citizens and the state institutions," (NDS 2015,14) which basically means that collectivities are the ones that ensure the transfer of security from state to individual level and vice versa. What is evident from these clarifications on security culture is that, in light of societal transformations we have examined in the first section, it has become obvious that the levels at which security operates have become entwined and the positive or negative evolution of one will intrinsically affect the others, idea which is reflected in one of the final paragraphs of NDS 2015 (NDS 2015, 23): the development of security culture entails a coordinated, joint and consistent effort at the level of the political class and civil society.

The new National Defense Strategy 2020-2024. Together for a Strong and Prosperous Romania in a World Marked by New Challenges (NDS 2020) mentions security culture more times with a focus on resilience both with respect to the state institutions and to the citizens. It correlates more strongly the actions taken at state level with the effects they have on the citizens and acknowledges that the security of the states is directly impacted by the security culture of the individuals. This change occurs in light of the transformations to the informational environment that we have discussed in section 1, changes which have a direct impact on the citizens, as the targets of disinformation campaigns are firstly individuals, and when they go viral, and become diffused in society, they can alter security at the higher level of collectivities and the state as such. Given the nature of social media and the online environments, resilience needs to be built both from the bottom up, from the citizens to the state, but also from the top down, as state institutions themselves need to become more resilient in face of informational attacks. According to NDS 2020, security culture is based on "the development of quick and efficient reaction mechanisms, (...) for citizens included" (NDS 2020, 6). Security culture is seen as an essential "enhancer of Romania's resilience" and as a promoter of national security values, and, consequently, it needs to increase and include as many societal and generational population segments as possible (NDS 2020, 10). The citizens' security culture is intercorrelated with the national goal of creating a powerful and resilient state, due to the new challenges in the international security environment which call for the development of comprehension, prevention and reaction mechanisms for the citizens when they are faced with threats, risks and vulnerabilities that impact national security (NDS 2020, 12). NDS 2020 focuses much more both on security culture as much needed for citizens' resilience capacity in the face of outside threats and risks and on the changes in the informational environment which pose dangers due to disinformation and hostile informational operations. A precarious or distorted security culture among citizens but also institutions is analyzed as both a risk (NDS 2020, 28) and a vulnerability (NDS 2020, 29) for national security and, therefore, building a resilient security culture in public and 
private institutions which manage strategic information is enumerated among the national security objectives (NDS 2020, 16).

Agency with respect to the actions that the objectives presuppose is somewhat unclear, but what can be deduced from the way the themes are formulated is that agency is no longer one-sided, from state institutions to the civil society. Rather, it becomes a collaborative effort, in which the relevant themes with respect to threats, risks, vulnerabilities are constructed through dialogue. This societal conversation ensures the greater understanding and meaning building with respect to security and how it is relevant for each individual and it also constructs individual responsibility with respect to active involvement in developing security culture at the level of the community and eventually the state. Inherently, the way the objectives are presented in NDS 2020 points to the fact that agency is no longer viewed as top-bottom but both as a horizontal and a vertical process whose aim is to create accountability and responsibility among citizens as well, with a view to creating a public discourse that enforces and promotes security culture at all levels.

Special attention is paid and clear reference is made to the actions needed to ensure a robust security culture among decision makers, as they are privy to classified information that must be handled with great care in the information age, when cyber attacks have become very frequent. In this respect, the security culture that is referenced is more narrow in scope, and it refers precisely to building an understanding of what classified documents and intelligence are and how they need to be protected.

In the previous Strategy (NDS 2015), the development and consolidation of security culture was mentioned briefly only in the section regarding "The educational, healthcare, social and demographic dimension" (NDS 2015, 22). In the current strategy it is also included in "The intelligence, counterintelligence and security dimension", with direct reference to the consolidation of security culture at the decision-making level, where classified information is managed and raising awareness with respect to the main counterintelligence risks and vulnerabilities which can facilitate threats to national security and have a major impact on national interests (NDS 2020, 35). NDS 2020 also correlates courses of action with national security objectives and explicitly mentions that this is a permanent, interinstitutional effort based on the continuous dialogue between institutions and citizens in the spirit of building and reinforcing security culture and societal resilience (NDS 2020, 40). Moreover, a legislative action is mentioned as NDS 2020 refers to the fact that "a coherent and applied legislative framework, aimed at strengthening the security culture and modernising the institutions with responsibilities in the field of national security" is needed. Thus, this strategy includes a measure that can address, via legislative means, the promotion of security culture at an institutional level.

\section{CONCLUSIONS}

In conclusion, what the analysis has revealed is that the attention given in Romania's National Defense Strategies to security culture is proportionate to the increase in the types and numbers of threats and risks posed by disinformation campaigns that target the security values liberal democratic societies are based on. These threats could be very efficient because a lack of resilience of the civil society and state institutions caused by a precarious security culture, more precisely a lack of understanding and assimilation of the values, norms and actions that it is based on, increases risks and vulnerabilities which can only be mitigated by conjugated actions taken at a state, collective and individual level to develop, promote, educate the public with respect to security culture. It can be noticed that while the objectives proposed are clear, the agency is less clearly defined. It is understood, rather than clearly stated, that in order to build security culture a concerted effort is needed on the part of state and civil organizations, however, a definite framework for such collaboration is not set. One aspect that NDS 2020 makes clear is that there are no longer clearly defined roles of agents and audiences. Both citizens and state institutions can and do play both roles, as collaboration in this democratic informational environment is the key element for trust and resilience building. Special attention is played to the fact that the citizens as well as the state institutions are responsible for building and promoting a resilient security culture. This is a medium if 
not long-term project that involves all levels of society and whose aim is to ensure a resilient state and citizenry in face of the new informational challenges. Security culture depends on a common understanding of the values that it is based on, on adherence to the norms that it presupposes and on concerted actions meant to enforce it in society.

\section{REFERENCES}

Buzan, B. 1997. "Rethinking Security after the Cold War. Cooperation and Conflict. 5-28

Buzan, B. Wæver, O. de Wilde, J. Security. 1998. A New Framework for Analysis. Lynne Rienner Publishers.

Gray, C.S. 2006. Out of the Wilderness: Prime Time for Strategic Culture. United States Nuclear Strategy Forum.

Johnston, A.I. 1995. "Thinking about Strategic Culture." International Security. vol.19. no.4. 32-64.

Kavanagh, Jennifer \& Rich, Michael D. 2018. Truth Decay, RAND report. The RAND Corporation. Santa Monica. California.

Kroeber A. L., Kluckhohn C. 1952. Culture: A Critical Review of Concepts and Definitions. The Museum, Cambridge, MA.

Møller, B. 2000. "The Concept of Security: The Pros and Cons of Expansion and Contraction." Paper for joint sessions of the Peace Theories Commission and the Security and Disarmament Commission at the $18^{\text {th }}$ General Conference of the International Peace Research Association.

Pye, L.W. 1985. Asian Power and Politics: the Cultural Dimension of Authority, Cambridge Massachusetts: Harvard University Press.

Roer, K. 2015. How to Build a Security Culture. Cambridgeshire: IT Governance Publishing.

Rosen, S.P. 1996. Societies and Military Power: India and Its Armies. Ithaca NY. Cornell University Press.

Singer, P.W. and Brooking, Emerson T. 2018. LikeWar. The Weaponization of Social Media. An Eamon Dolan Book. Houghton Mifflin Harcourt. Boston. New York.

Snyder, J.L. 1977. The Soviet Strategic Culture: Implications for Limited Nuclear Operations. A project AIR FORCE Report prepared for the United States Air Force, Rand.

*** National Defense Strategy 2015-2019. A Strong Romania within Europe and the World available at http://old.presidency.ro/static/National\%20\%20Defense\%20Strategy\%202015\%20-

\%202019.pdf

*** Guide to the National Defense Strategy http://www.presidency.ro/files/userfiles/Ghid SNApT_2015-2019_AP.pdf

*** National Defense Strategy 2020-2024. Together for a Strong and Prosperous Romania in a World Marked by New Challenges available at https://www.presidency.ro/files/userfiles/ National_Defence_Strategy_2020_2024.pdf

*** Strategia Națională de Apărare 2010, available at http://www.cdep.ro/caseta/2010/08/31/ hp100622_CSAT.pdf 